Article

\title{
Effect of Bactericides on Control of Acidification Pollution and Spontaneous Combustion of Coal Gangue Dumps in China and Its Mechanism
}

\author{
Zhenqi Hu ${ }^{1,2, *}$, Qi Zhu ${ }^{1}{ }^{1}$, Jingjing $\mathrm{Xu}^{3}$ and Xue Zhang ${ }^{1}$ \\ 1 Institute of Land Reclamation and Ecological Restoration, China University of Mining and \\ Technology (Beijing), Beijing 100083, China; bqt1700204045@student.cumtb.edu.cn (Q.Z.); \\ sqt1800204101@student.cumtb.edu.cn (X.Z.) \\ 2 School of Environment Science and Spatial Informatics, China University of Mining and Technology, \\ Xuzhou 211116, China \\ 3 School of Resources and Environment, Henan University of Engineering, Zhengzhou 451191, China; \\ tsp150202086@student.cumtb.edu.cn \\ * Correspondence: huzq@cumtb.edu.cn; Tel.: +86-10-6233-9045
}

Received: 6 July 2020; Accepted: 13 August 2020; Published: 19 August 2020

\begin{abstract}
Oxidation of pyrite in the coal gangue dumps usually results in acidification and spontaneous combustion, causing many environmental problems such as air, soil, and water pollution. The oxidizing bacteria exacerbate problems such as acidification, spontaneous combustion, and explosions. The bacterium Acidithiobacillus ferrooxidans was first separated and isolated from coal gangue samples. Bactericides such as Triclosan, Kathon (isothiazolinones), and sodium dodecyl sulfate (SDS) were selected for our study. Our findings indicated that the addition of bactericide effectively inhibited the oxidation of $\mathrm{Fe}^{2+}$, preventing $\mathrm{pH}$ decreases and oxidation-reduction potential increases. We also investigated the bactericidal mechanisms employed by the three bactericides against $A$. ferrooxidans by conducting a protein flocculation test, scanning electron microscopy, and time-of-flight mass spectrometry. We found that the specific inhibitory activities of the three bactericides differed. Kathon treatment caused A. ferrooxidans to release small amounts of proteins and lipids. A. ferrooxidans treated with Triclosan released small amounts of lipids and large amounts of plasmas. SDS caused the bacteria to release a large amount of proteins and lipids and degraded the surface structure of the cells, resulting in altered cell morphology.
\end{abstract}

Keywords: acid coal gangue dump; acidification pollution; bactericide; inhibition of oxidation; Acidithiobacillus ferrooxidans

\section{Introduction}

Coal gangue is an inevitable product of the process of coal mining and processing and is the main pollution source in coal mines [1]. The main source of acid coal gangue pollution and subsequent environmental disasters is the oxidation of sulfide. In the open storage process, sulfide contained in coal gangue easily forms acid mine drainage (AMD) containing high concentrations of sulfate and a diversity of harmful heavy metal ions through comprehensive actions such as air oxidation, rainwater eluviation, and microorganism activity [2,3]. Therefore, controlling the oxidation of sulfides in coal gangue has become an important means of mitigating the effects of acidification of coal gangue.

Studies in China and abroad have found that the oxidation process of pyrite in coal gangue is affected by the biocatalysis of oxidizing bacteria such as Acidithiobacillus ferrooxidans (A. ferrooxidans), significantly accelerating the conversion of $\mathrm{Fe}^{2+}$ to $\mathrm{Fe}^{3+}$, increasing the reaction rate by 50 to 60 times, and playing a vital role in acid pollution [4]. In 1947, Colmer et al. discovered and isolated a strain of 
A. ferrooxidans in Pittsburgh that could carry out ferrous oxidation in AMD, confirming the bio-oxidation processing of ferrous iron [5]. Leathen et al., 1953, first proposed that acid pollution in coal gangue is controlled by the activity of microorganisms [6]. Nosa believes that AMD is formed by the oxidation of sulfur minerals (mainly pyrite, $\mathrm{FeS}_{2}$ ) in mine tailings by the combined action of chemical oxidants $\left(\mathrm{O}_{2}, \mathrm{Fe}^{3+}\right)$ and A. ferrooxidans [7].

Antimicrobial agents can significantly affect environmental microbial activity. Researchers began to study the use of bactericides to reduce oxidation and acid production in the treatment of coal gangue in the 1980s [8,9]. Since 1981, Kleinmann, Schippers, and others have studied the germicidal efficacy of benzoic acid, sorbic acid, sodium alkyl benzene sulfonate, and SDS. Their results showed that the strongest bacteriostatic agent among these is SDS [10,11]. Peng et al. examined the effects of the surfactant Tween- 80 on the sulfur metabolism of $A$. ferrooxidans and confirmed that the surfactant has an effect on extracellular proteins, cell EPS composition, and expression of EPS synthesis-related genes in A. ferrooxidans [12]. Publishing as part of a long-term scientific cooperative project with Germany and Romania, Sand et al. concluded that isothiazoline, organic materials, and crushed limestone coatings reduce the release of metals and sulfur from coal mine wastes [13]. Hu et al. conducted an experiment using two bactericides, namely sodium dodecyl sulfate (SDS) and sodium benzoic (SBZ), to control the acidification of coal gangue. Their results show that when the concentration of SDS is $10 \mathrm{mg} / \mathrm{L}$ or the concentration of SBZ is $30 \mathrm{mg} / \mathrm{L}$, the oxidation of $\mathrm{Fe}^{2+}$ can be inhibited by approximately $75 \%$ [14].

In recent years, many scholars have focused on bactericides constituting low environmental hazards, such as food preservatives and anionic surfactants. The bactericide SDS is a food preservative with little negative impact on the environment and possesses good sterilization effects. Kathon is a nonoxidizing bactericide with high efficiency and broad spectrum, is effective over a wide $\mathrm{pH}$ range [15], and it can be naturally degraded to an innocuous substance at the concentrations used, resulting in no pollution to the environment [16]. It has been demonstrated to be effectively lethal to microorganisms in the soil [17]. Triclosan is a broad-spectrum antibiotic with the chemical name 2,4,4'-trichloro-2'-hydroxy diphenyl ether. Triclosan can inhibit bacteria effectively and kills Gram-positive and Gram-negative bacteria, yeast, and viruses [18]; therefore it is widely used in various household disinfectant products. As early as the 1960s, the United States began to use Triclosan to produce deodorizing soap and deodorant, and Europe began to produce toothpaste containing Triclosan [19]. The inhibitory effect of bactericides on A. ferrooxidans may exhibit at different points of action. To better detect the action of bactericides on A. ferrooxidans, it is necessary to observe the protein in vivo, along with ultrastructure and lipids. Bactericide treatment may rupture of cell walls and membranes, producing a protein efflux in A. ferrooxidans. To detect whether there is a protein release, preliminary observations were made using a protein flocculation precipitate. Scanning electron microscopy detected surface damage and dents on bacteria. The cellular lipids released were measured using time-of-flight mass spectrometry.

In this paper, three high-efficiency, environmentally friendly bactericides, SDS, Kathon, and Triclosan, were used to study their inhibitory effects on the oxidation activity of A.ferrooxidans. Moreover, optimal application concentrations and bacteriostatic mechanisms were determined. This paper discusses the possibility of using bactericides to neutralize bacterial oxidation and the generation of acidic pollution, laying a foundation for the development of fungicidal materials suitable for in situ control of acidification pollution in coal gangue dumps in China.

\section{Materials and Methods}

\subsection{Test Strains and Drugs}

The original bacterial strain used in this study came from a coal gangue dump in Yangquan, Shanxi, China. A coal gangue sample $(5 \mathrm{~g})$ was added to $50 \mathrm{~mL}$ of sterile water and oscillated at $160 \mathrm{rpm}$ for 3 days at a constant temperature of $30^{\circ} \mathrm{C}$. The solution was then filtered through paper to obtain a coal gangue soak solution containing bacteria; $70 \mathrm{~mL}$ of iron-free $9 \mathrm{~K}$ medium $(\mathrm{pH}=1.80$, sterilized at $121^{\circ} \mathrm{C}, 30 \mathrm{~min}$ ), $20 \mathrm{~mL}$ of coal gangue soak solution, and $10 \mathrm{~mL}$ of $\mathrm{Fe}^{2+}$ stock solution (filter-sterilized; 
containing $40 \mathrm{~g} / \mathrm{L} \mathrm{Fe}^{2+}$ in the form of $\mathrm{FeSO}_{4} \cdot 7 \mathrm{H}_{2} \mathrm{O}$ ) were combined. The flask was incubated in a thermostatic bath $\left(30^{\circ} \mathrm{C}, 160 \mathrm{rpm}\right)$. After 7 days, the solution became reddish brown, iron precipitates formed, and the bacterial numbers reached $10^{7}-10^{8} / \mathrm{mL}$. A. ferrooxidans was sub-cultured twice in the liquid medium and after serial dilution plated on to a solid medium $(0.3 \%$ sodium citrate and $0.016 \%$ $\mathrm{CuSO}_{4}$ in $9 \mathrm{~K}, 2 \%$ agarose; all in $\left.w / v\right)$. Single colonies were selected for RNA extraction (FastDNA spin kit for soil, MP Biomedicals, Irvine, CA, USA) and 16S rRNA gene sequencing (ABI 3730XL, Applied Biosystems, Foster City, CA, USA). The strain was identified to be a $99.04 \%$ homologous to Acidithiobacillus ferrooxidans strain YTW (DQ062116.1) by using 16S rRNA gene sequencing and named Acidithiobacillus ferrooxidans strain AF-14 (MT774373).

The reagents used in the experiments were all analytically pure Analytical Reagent (AR). The bactericide purities of Kathon (2.5\% solution, Changzhou Xinnuoke Chemical Co. LTD, Changzhou, China), SDS (powder, Biofroxx, Einhausen, Germany), and Triclosan (powder, Hefei BASF Biotechnology Co. LTD, Hefei, China) were AR, and they were sterilized by filtration through a $0.22 \mu \mathrm{m}$ PVDF membrane.

\subsection{Experimental Methods}

\subsubsection{Determination of Optimal Application Concentrations}

Bacterial solution $(10 \mathrm{~mL}), 70 \mathrm{~mL}$ of iron-free $9 \mathrm{~K}$ medium (heat sterilized as described above) and $10 \mathrm{~mL}$ of the $\mathrm{Fe}^{2+}$ stock solution (also described above) were added to fifteen $250 \mathrm{~mL}$ sterilized conical flasks at an aseptic operation station. Kathon $(10 \mathrm{~mL})$ was added from sterile, 10 -fold concentrated stock solutions to final concentrations 0 (control), 15, 30, 64 and $122 \mathrm{mg} / \mathrm{L}$ in the cultures. Each bactericide concentration was tested in triplicate. Similar procedure was followed with Triclosan and SDS, Triclosan with final concentrations of $0,4,8,16,28$, and $36 \mathrm{mg} / \mathrm{L}$ (each tested in duplicate), SDS with final concentrations of $0,5,10,30,50$, and $100 \mathrm{mg} / \mathrm{L}$ (each tested in duplicate). The control group was supplemented with $100 \mathrm{~mL}$ of $9 \mathrm{~K}\left(\mathrm{Fe}^{2+}\right)$ medium, sealed, and cultured at a constant temperature and rate of agitation $\left(30^{\circ} \mathrm{C}, 160 \mathrm{rpm}\right)$. To determine the optimal application concentration of Kathon, the $\mathrm{pH}$ of the bacterial solution, the oxidation-reduction potential $\mathrm{Eh}$, and the rate of $\mathrm{Fe}^{2+}$ oxidation were measured at different times. The $\mathrm{pH}$ and Eh were measured by $\mathrm{pH}$ and redox electrode (coupled to $\mathrm{pH}$ and Eh meters, DZS-708L, INESA Scientific Instrument Co., Ltd. Shanghai, China). Ferrous iron concentrations were determined by the EDTA complexometric titration [20].

\subsubsection{Disk Inhibition Zone Experiment}

The disk inhibition zone experiment is an experimental method to determine the bactericidal effect by the degree of spread of bactericides on solid culture medium; $0.1 \mathrm{~mL}$ of bacterial culture was evenly spread onto each of 12 plates containing the solid medium described in Section 2.1. Triplicate plates were labeled No. 1-No. 4 and treated with $0.02 \mathrm{~mL}$ of Kathon $(30 \mathrm{mg} / \mathrm{L})$, Triclosan $(16 \mathrm{mg} / \mathrm{L})$, SDS (10 mg/L) and sterile water (control treatment), respectively. A $6 \mathrm{~mm}$ diameter hole was punched in the center of solid culture medium in each petri dish, and bactericide or sterile water was injected into the holes. After that, the petri dishes were placed in an incubator at a constant temperature of $30^{\circ} \mathrm{C}$ for about $15 \mathrm{~d}$, and the size of disk inhibition zone was observed.

\subsubsection{Protein Flocculation Test}

Five replications of the bacterial solution (cultures grown in $9 \mathrm{~K}$ without the addition of any bactericide) were centrifuged at 10,000 rpm for $20 \mathrm{~min}$, and the cells were collected. The cells were mixed well with $1 \mathrm{~mL}$ EDTA, transferred to a $2 \mathrm{~mL}$ EP tube, and centrifuged at 12,000 rpm for $10 \mathrm{~min}$. The supernatant was discarded. This was repeated one more time, to remove metal ions from the medium.

The $1 \mathrm{~mL}$ cell suspensions in EDTA were used as positive controls (No. 1), with $980 \mu \mathrm{L}$ sodium phosphate buffer (SPB) and $122 \mu \mathrm{L}$ of MT buffer from a total DNA extraction kit (FastDNA spin kit for 
soil, MP Biomedicals) added. After mixing well, the solution was lysed in Matrix E tubes. When the solution temperature reached room temperature, it was shaken in a fastprep (bead mill oscillator) for $40 \mathrm{~s}$. This was repeated six times before the cell beads were crushed.

Bactericide (1 mL) was added (No. 2: $1 \mathrm{~mL}, 30 \mathrm{mg} / \mathrm{L}$ for Kathon; No. 3: $1 \mathrm{~mL}, 16 \mathrm{mg} / \mathrm{L}$ for Triclosan; No. 4: $1 \mathrm{~mL}, 10 \mathrm{mg} / \mathrm{L}$ for SDS), mixed well and left to stand for $3 \mathrm{~h}$.

As a negative control, $1 \mathrm{~mL}$ of full $9 \mathrm{~K}$ medium (containing $\mathrm{Fe}^{2+}$ ) was added to No. 5, mixed, and let stand for $3 \mathrm{~h}$.

All samples, No. 1-No. 5, were centrifuged at 12,000 rpm for $10 \mathrm{~min}$, and the supernatant was transferred to new $2 \mathrm{~mL}$ EP tubes. After, the protein precipitation solution (PPS, $250 \mu \mathrm{L}$ ) was added, and the tubes were inverted. The role of the PPS solution was to denature the protein. Treatment with PPS produced a milky flocculent material. Photographs were taken and observations made with a stereomicroscope. The appearance of a milky precipitate indicated a release of proteins as a result of bactericide treatment.

\subsubsection{Observations Using a Scanning Electron Microscope}

The bacterial solution ( $300 \mathrm{~mL}$, in Section 2.1) to be tested was divided into 12 centrifuge tubes (25 mL). Triplicate plates were labeled No. 1-No. 4. Each group had 4 centrifuge tubes, centrifuged at 13,000 rpm for $20 \mathrm{~min}$. The supernatants were discarded, and the precipitates containing bacteria were collected. The precipitates were then suspended in $1 \mathrm{~mL}$ of acidified $\mathrm{H}_{2} \mathrm{O}$ (with $\mathrm{HCl}$ to $\mathrm{pH}$ 1.8), transferred to $1.5 \mathrm{~mL}$ centrifuge tubes, centrifuged for $10 \mathrm{~min}$ at $12,000 \mathrm{rpm}$. The supernatant was discarded, leaving the bacteria bearing precipitate (iron removal). No. 1 was suspended in $1 \mathrm{~mL}$ of Kathon, No. 2 with $1 \mathrm{~mL}$ of Triclosan, No. 3 with $1 \mathrm{~mL}$ of SDS, and No. 4 with $1 \mathrm{~mL}$ of sterile water. These were cultured for $3 \mathrm{~h}$ on a shaking table at $160 \mathrm{rpm}$ with a constant temperature of $30{ }^{\circ} \mathrm{C}$. They were centrifuged at $12,000 \mathrm{rpm}$ for $10 \mathrm{~min}$. The supernatants were removed and combined with $1 \mathrm{~mL}$ of phosphate buffer $\left(0.047 \mathrm{~mol} / \mathrm{L} \mathrm{g}\right.$ of $\mathrm{Na}_{2} \mathrm{HPO}_{4} \cdot 12 \mathrm{H}_{2} \mathrm{O}$ and $0.020 \mathrm{~mol} / \mathrm{L}$ of $\mathrm{KH}_{2} \mathrm{PO}_{4}$, with the $\mathrm{pH}$ adjusted to 7.2 with $\mathrm{H}_{2} \mathrm{SO}_{4}$ ) and repeated 2 more times. The sample was fixed with $2.5 \%$ glutaraldehyde, held overnight at $4{ }^{\circ} \mathrm{C}$, and centrifuged at $9000 \mathrm{rpm}$ for $15 \mathrm{~min}$, after which the supernatants were discarded and the samples were dehydrated with a gradient of $30 \%, 50 \%, 75 \%$, $90 \%$, and $100 \%$ ethanol. The cells were then freeze-dried at different gradient temperatures of $-20{ }^{\circ} \mathrm{C}$, $-40{ }^{\circ} \mathrm{C},-60^{\circ} \mathrm{C}$, and $-80^{\circ} \mathrm{C}$, allowed to stand at each temperature step for $12 \mathrm{~h}$, then observed using a scanning electron microscope (SEM).

\subsubsection{Time-of-Flight Mass Spectrometry for the Determination of Intracellular Lipid Efflux}

Bacterial solutions $(10 \mathrm{~mL})$ were mixed with iron-free $9 \mathrm{~K}$ medium $(70 \mathrm{~mL}$, described above), $\mathrm{Fe}^{2+}$ stock solution $(10 \mathrm{~mL}$, described above), and sterile water $(10 \mathrm{~mL})$ in $250 \mathrm{~mL}$ sterilized conical flasks, which were sealed and cultured under constant temperature and agitation $\left(30^{\circ} \mathrm{C}, 160 \mathrm{rpm}\right)$.

Four sample groups $(10 \mathrm{~mL})$ were centrifuged at $1000 \mathrm{rpm}$ for $5 \mathrm{~min}$. The supernatant was transferred to a new centrifuge tube and centrifuged at 10,000 rpm for $10 \mathrm{~min}$. The supernatants were discarded, and the viscous material attached to the walls of the centrifuge tubes was washed with $1 \mathrm{~mL}$ of Kathon, Triclosan, SDS, or sterile water at a $\mathrm{pH}$ of 1.8 . These were then cultured at $30^{\circ} \mathrm{C}$ and $160 \mathrm{rpm}$ for $3 \mathrm{~h}$ and subjected to time-of-flight mass spectrometry.

\section{Results and Discussion}

\subsection{Effect of Different Concentrations of Bactericides on $\mathrm{Fe}^{2+}$ in Culture Medium}

Figure 1 shows the differences in the inhibition rate at different bactericide concentrations. All the $\mathrm{Fe}^{2+}$ in the control treatment was oxidized rapidly within $48 \mathrm{~h}$. Following the addition of bactericide, the rate of $\mathrm{Fe}^{2+}$ oxidation decreased to some extent in each treatment, probably because the growth of AF-14 was inhibited. 


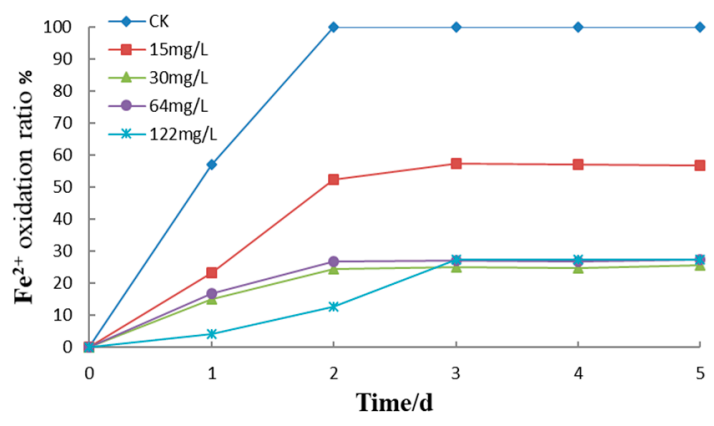

(a) $\mathrm{Fe}^{2+}$ oxidation ratio

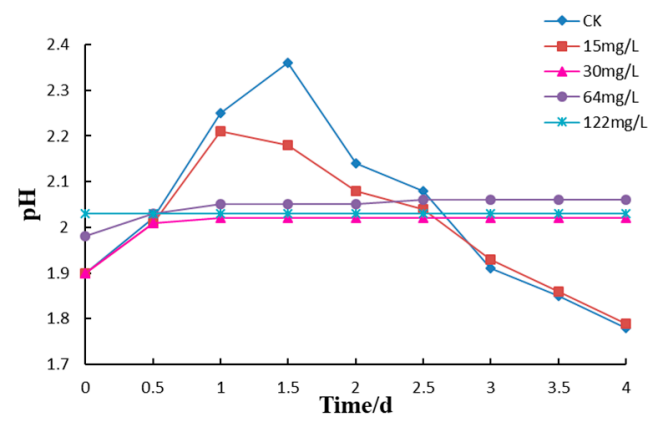

(b) $\mathrm{pH}$

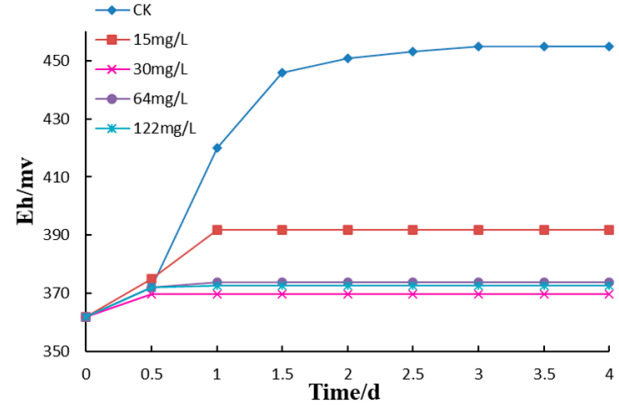

(c) $\mathrm{Eh}$

Figure 1. Time course of (a) iron oxidation, and (b) pH and (c) Eh changes in AF-14 cultures at varying concentrations of Kathon.

Figure 1 shows that there is a critical value that constitutes an optimal application concentration. When the concentration is less than this value, increasing the bactericide concentration significantly reduces the $\mathrm{Fe}^{2+}$ oxidation. When the concentration reaches this value, increasing the bactericide concentration does not have an obvious effect on $\mathrm{Fe}^{2+}$ oxidation. Sand et al. demonstrated that an addition of the biocide isothiazolinone up to $100 \mathrm{mg} / \mathrm{L}$ kills bacteria and reduces the release of $\mathrm{Cu}, \mathrm{Zn}$, $\mathrm{Fe}$, and sulphate by $5 \%$ to $50 \%$ for different types of mine waste [13]. As seen in Figure $1 \mathrm{a}$, as the Kathon concentration reached a critical value at $30 \mathrm{mg} / \mathrm{L}$, the $\mathrm{Fe}^{2+}$ oxidation rate in the bacterial solution increased slightly within the first $48 \mathrm{~h}$ and subsequently reached a stable value of $24.35-25.75 \%$.

The $\mathrm{pH}$ and oxidation-reduction potential (Eh) can also reflect the oxidation of $\mathrm{Fe}^{2+}$. As seen in Figure $1 \mathrm{~b}$, when the concentration of Kathon was below $30 \mathrm{mg} / \mathrm{L}$, the $\mathrm{pH}$ of bacterial solution first increased (within 0-36 h) and then decreased. The reason is that a large amount of acid was consumed during $\mathrm{Fe}^{2+}$ oxidation, which increased the $\mathrm{pH}$ of the bacterial solution significantly. Subsequently, greater amounts of $\mathrm{Fe}^{3+}$ were oxidized, and the jarosite formed after hydrolysis caused the $\mathrm{pH}$ of the bacterial solution to drop rapidly. In addition, the time course of Eh (Figure 1c) followed the course of $\mathrm{Fe}^{2+}$ oxidation in Figure 1a. In Kathon treatments with concentration $>30 \mathrm{mg} / \mathrm{L}$, no changes in $\mathrm{pH}$ or Eh were observed, indicating that $30 \mathrm{mg} / \mathrm{L}$ of the bactericide effectively inhibits the oxidation of $\mathrm{Fe}^{2+}$.

Similarly, concentration of Triclosan $>16 \mathrm{mg} / \mathrm{L}$ significantly reduced the oxidation rate of $\mathrm{Fe}^{2+}$ in the culture to 14.62 to $16.52 \%$. Higher Triclosan concentrations $(>16 \mathrm{mg} / \mathrm{L})$ did not reduce $\mathrm{Fe}^{2+}$ oxidation rate further, indicating $16 \mathrm{mg} / \mathrm{L}$ was the optimal application concentration. There was no significant difference between the treatments with different concentrations of Triclosan, indicating that the optimal application concentration of Triclosan was $16 \mathrm{mg} / \mathrm{L}$. The optimal application concentration for SDS was $10 \mathrm{mg} / \mathrm{L}$, and the oxidation rate of $\mathrm{Fe}^{2+}$ could be inhibited to $16.24 \%$ or less after 5 days. Repeated $100 \mathrm{mg} / \mathrm{L}$ of SDS treatment performed by Schippers et al. resulted in long term inhibition of leaching microorganisms in $65 \mathrm{~m}^{3}$ percolators [11]. Our experimental results were much lower than this value, and they were consistent with the study by Onysko et al., which indicated that $\geq 5 \mathrm{mg}$ of SDS per liter effectively inhibited biological ferrous iron oxidation [9]. 


\subsection{Comparison of the Inhibition Effect of Bactericides on AF-14 Growth}

AF-14 grew brownish-red colonies on solid media, and a disk inhibition zone without colonies was formed on the medium in contact with the bactericide because AF-14 growth was inhibited. As shown in Table 1, the diameter of disk inhibition zone differed for different treatments. The injection of sterile water into the holes had no effect on growth of AF-14, and the diameter of the disk inhibition zone was equal to the hole diameter. The diameters of disk inhibition zones of the three bactericides were SDS > Triclosan > Kathon from greatest to smallest, indicating SDS had the greatest inhibitory effect on growth of AF-14. The bactericidal strength of bactericide was proportional to the diameter of disk inhibition zone, so that SDS had the greatest inhibitory effect on growth of AF-14.

Table 1. Disk inhibition zone diameters for different bactericides (including hole diameter $6 \mathrm{~mm}$ ).

\begin{tabular}{cc}
\hline Bactericide & Diameter of Disk Inhibition Zone (mm) \\
\hline Sterile water & 6.00 \\
SDS & 20.0 \\
Kathon & 10.9 \\
Triclosan & 19.6 \\
\hline
\end{tabular}

\subsection{Analysis of the Bacteriostatic Mechanism of Bactericides against AF-14}

\subsubsection{Effects of Bactericides on Bacterial Proteins}

In Figure 2, No. 1 is a positive control sample, in which the bacteria were disrupted using a bead mill oscillator. The resulting complete release of proteins from the cells formed a milky flocculation precipitate. On the other hand, no flocculation precipitates were observed in a negative control (No. 5; a culture without any disruptions or bactericide additions). No. 2 was a bacterial solution treated with Kathon. The flocculation precipitate formed in this sample was greater than in No. 3 treated with Triclosan that showed no flocculation precipitate. The comparison indicates that Kathon causes protein efflux from AF-14 cells, while Triclosan does not. The protein flocculation precipitate in No. 4 with SDS was slightly greater than that in No. 2, suggesting that SDS had an even stronger effect on protein efflux than Kathon.

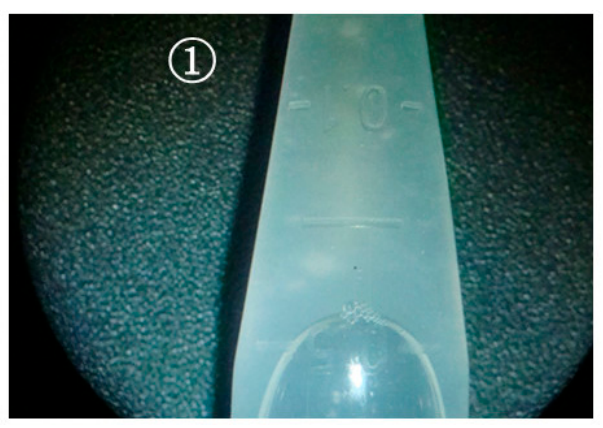

(a) Positive control

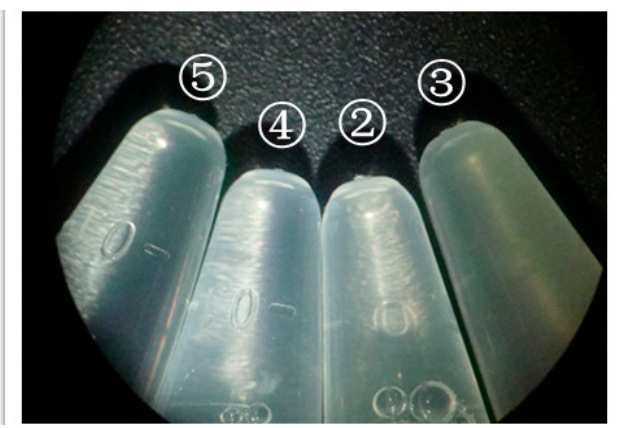

(b) Kathon, Triclosan, SDS and negative control

Figure 2. Protein flocculation precipitates in AF-14 cultures treated with (1) a bead oscillator (positive control), (2) Kathon, (3) Triclosan, and (4) SDS, compared to (5) a negative control (untreated AF-14).

The above results suggest that a critical amount of Kathon had the same effect as SDS. However, Triclosan alone had a negligible effect on the proteins of AF-14.

\subsubsection{Effects of Bactericides on Bacterial Surfaces}

As seen in Figure 3a, AF-14 was full in shape, smooth on surface, and had good light refraction. 


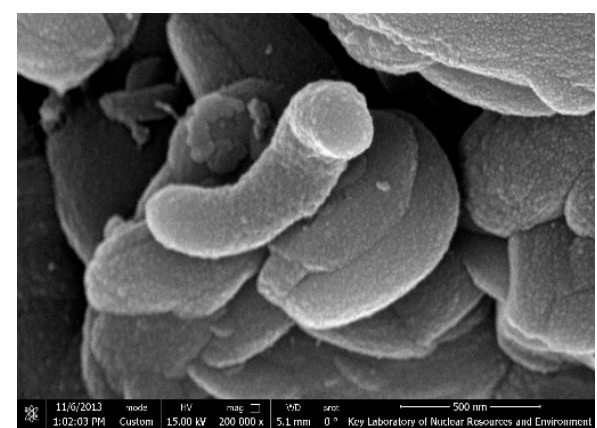

(a) Untreated A. ferrooxidans cells

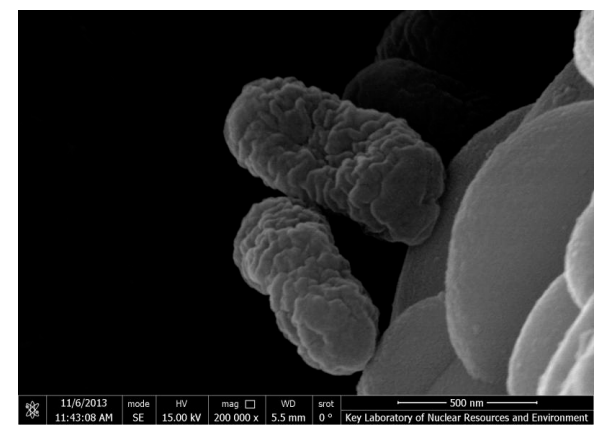

(c) Kathon

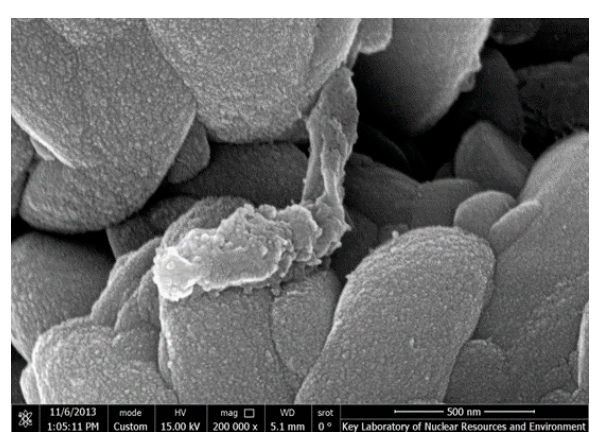

(b) SDS

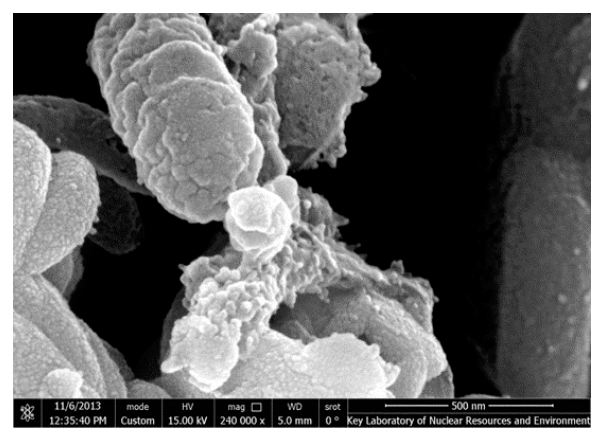

(d) Triclosan

Figure 3. A. ferrooxidans cells after $3 \mathrm{~h}$ of bactericide treatment compared to intact cells.

As shown in Figure 3b, $3 \mathrm{~h}$ after SDS was added, the cells were damaged and shrunken. The cell shape was distorted, with the presence of a viscous material on the surface. Consistent with Siebert et al., these findings demonstrated that SDS causes cell lysis, releasing nucleic acids [21]. This indicated that SDS destroyed the bacteria surfaces, inhibiting $A$. ferrooxidans activities.

As seen in Figure 3c, after $3 \mathrm{~h}$ of treatment with Kathon, AF-14 established with obvious cracks, shrinkage on cell surfaces, and large depressed areas and damage. In Figure $3 \mathrm{~d}$, Triclosan treatment changed the cellular morphology, and caused the release of a large amount of plasma; further, the surfaces of the cells adhered to the mucus and were corroded.

Scanning electron microscopy demonstrated that although SDS damaged the bacterial cell surface of AF-14, the cell contents were not released. After treatment with Kathon or Triclosan, irreversible damage to AF-14 had occurred. These results demonstrated that all three bactericides effectively inhibited AF-14, and that the inactivation occurred at different points of action, to different extents. These results may explain the finding of the study by Sand et al. that SDS only transiently reduced the number and activity of bioleaching bacteria, but isothiazolinone reduced the release of metals and sulphate to some extent [13].

\subsubsection{Effects of Bactericides on Bacterial Lipids}

Figure $4 \mathrm{a}$ shows the time-of-flight mass spectrometry results for the blank control group; Figure $4 \mathrm{~b}-\mathrm{d}$ represent the spectra for bacterial solutions treated with bactericides SDS, Triclosan, and Kathon, respectively.

In Figure 4a there are no peaks between $600 \mathrm{Da}$ and $900 \mathrm{Da}$, whereas there were such peaks observed in Figure $4 \mathrm{~b}-\mathrm{d}$. After comparison, a marker at 676.3 Da was detected, and the corresponding lipid structure was obtained by referring to the database Lipidbank, as shown in Figure 5.

There was almost no lipid efflux in the blank control (Figure 4a). When treated with SDS, the cell lipids were released at high volumes (Figure $4 \mathrm{~b}$ ). The time-of-flight mass spectrometry for the solution treated with Triclosan (Figure 4c) also showed a peak between $600 \mathrm{Da}$ and $900 \mathrm{Da}$, which indicated that some lipids could be secreted and that the internal structure of the bacteria was compromised. 
In contrast, the peak value between $600 \mathrm{Da}$ and $900 \mathrm{Da}$ for the Kathon treatment was lower and indicated a milder effect on lipids (Figure 4d).

These results show that the three bactericides had an effect on the lipids of AF-14, causing them to exit the cells to different extents. Among these treatments, SDS had a greater effect on lipids than did Triclosan and Kathon.

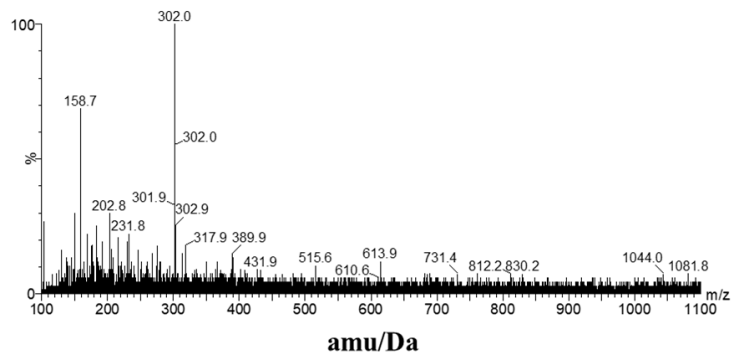

(a) Control

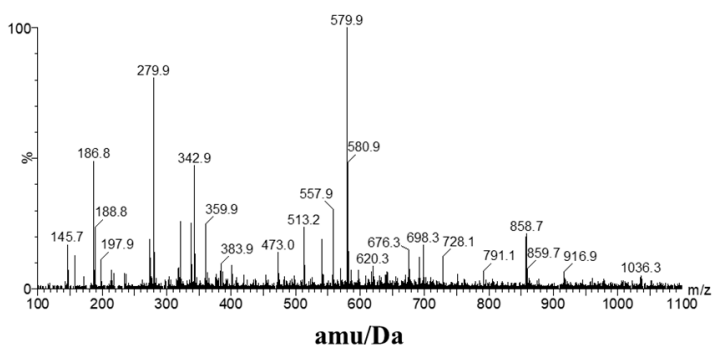

(c) Triclosan

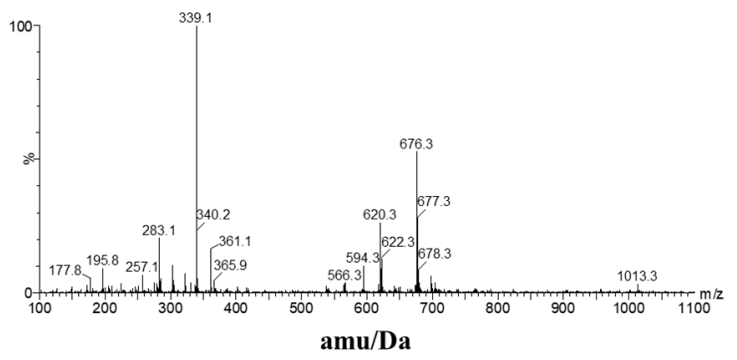

(b) SDS

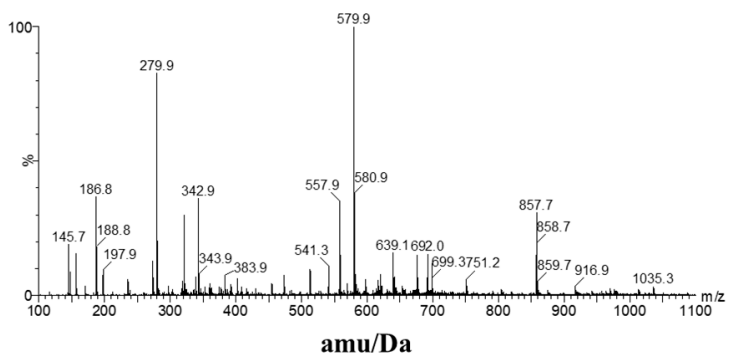

(d) Kathon

Figure 4. Spectra of cell lipids release (determined by time-of-flight mass spectrometry).

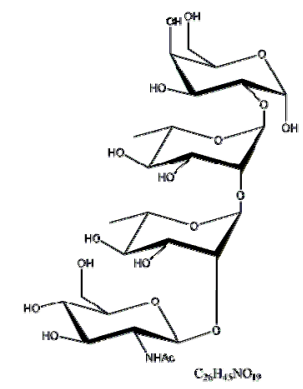

Figure 5. Structural formula of marker.

\section{Conclusions}

(1) Microbially mediated oxidation of pyrite in coal gangue dumps is the key process resulting in acidification and spontaneous combustion. The bactericides such as Triclosan, Kathon, and SDS can effectively inhibit the oxidation of iron by A. ferrooxidans, with the inhibition of $\mathrm{Fe}^{2+}$ oxidation reaching 75-83.5\%. The optimal application concentrations of Kathon, Triclosan, and SDS for A. ferrooxidans inhibition were $30 \mathrm{mg} / \mathrm{L}, 16 \mathrm{mg} / \mathrm{L}$, and $10 \mathrm{mg} / \mathrm{L}$, respectively.

(2) All three bactericides effectively inhibited A. ferrooxidans and inactivated the cells to various extents, using different mechanisms. Among these, Kathon caused A. ferrooxidans to release small amounts of proteins and lipids, resulting from cracks and shrinkage to cell surfaces after $3 \mathrm{~h}$ of treatment. Triclosan caused the release of a small amount of lipid, due to cell surface shrinkage and degradation after $3 \mathrm{~h}$. This caused the release of a large amount of plasma. Within $3 \mathrm{~h}$, SDS caused 
a large release of proteins and lipids, degraded the cell surface structure, and distorted the cellular morphology of the bacteria.

(3) The main source of acid coal gangue dump pollution and consequent environmental disasters has been the oxidation of sulfides in coal gangue. Catalytic oxidation by microorganisms (A.ferrooxidans) has been identified as a major mechanism; therefore, the use of bactericides that can effectively kill A. ferrooxidans and inhibit oxidation can help reduce the acid water and the risk of spontaneous combustion in coal gangue by fixing sulfur and lowering temperatures. Together, these strategies can control the spread of pollution and promote vegetative restoration.

Author Contributions: Conceptualization, Z.H. and Q.Z.; Methodology, J.X.; Software, J.X.; Validation, Q.Z. and J.X.; Data Curation, Q.Z. and X.Z.; Writing-Original Draft Preparation, Q.Z.; Writing-Review and Editing, Z.H. and X.Z.; Supervision, Z.H. All authors have read and agreed to the published version of the manuscript.

Funding: This research was funded by the Science and Technology Planning Project of Henan province, grant number 172102310746 and National Key Research and Development Program (grant numbers 2019YFC1805003).

Conflicts of Interest: The authors declare no conflict of interest.

\section{References}

1. Hu, Z.Q.; Yang, X.H.; Bao, Y.; Gao, X.J.; Luo, M.; Wang, J.; Long, H.L. On the restoration of mine Eco-environment. Sci. Technol. Rev. 2005, 23, 38-41.

2. Akcil, A.; Koldas, S. Acid mine drainage (AMD): Cause, treatment and case studies. J. Clean. Prod. 2006, 14, 1139-1145. [CrossRef]

3. Baker, B.J.; Banfield, J.F. Microbial communities in acid mine drainage. FEMS Microbiol. Ecol. 2003, 44, 139-152. [CrossRef]

4. Zhong, H.F.; Cai, W.L.; Li, Y.Q. Bacterial Oxidation of Pyrite. Acta Microbiol. Sin. 1987, 27, 264-270.

5. Colmer, A.R.; Hinkle, M.E. The role of microorganisms in acid mining drainage. Science 1947, 106, $253-256$. [CrossRef] [PubMed]

6. Leathen, W.W.; Braley, S.A.; Mcintyre, L.D. The Role of Bacteria in the Formation of Acid from Certain Sulfuritic Constituents Associated with Bituminous Coal. Appl. Microbiol. 1953, 1, 61-68. [CrossRef] [PubMed]

7. Egiebor, N.O.; Oni, B. Acid rock drainage formation and treatment: A review. Asia Pac. J. Chem. Eng. 2007, 2, 47-62. [CrossRef]

8. Gurdeep, S.; Miss, M.B. Inhibition of bacterial activity in acid mine drainage. Mine Water Environ. 1988, 7, 13-26.

9. Onysko, S.J.; Kleinmann, R.L.P.; Erickson, P.M. Ferrous iron oxidationby Thiobacillus ferrooxidans: Inhibition with benzoic acid, sorbicacid, and sodium lauryl sulphate. Appl. Environ. Microbiol. 1984, 48, $229-231$. [CrossRef] [PubMed]

10. Kleinmann, R.L.P.; Crerar, D.A.; Pacelli, R.P. Biogeochemistry of acid mine drainage and a method to control acid formation. Miner. Eng. 1981, 33, 300-305.

11. Schippers, A.; Jozsa, P.G.; Kovacs, Z.M.; Jelea, M.; Sand, W. Large-scale experiments for microbiological evaluation of measures for safeguarding sulfidic mine waste. Waste Manag. 2001, 21, 139-146. [CrossRef]

12. Peng, A.A.; Liu, H.C.; Nie, Z.Y.; Xia, J.I. Effect of surfactant Tween-80 on sulfur oxidation and expression of sulfur metabolism relevant genes of Acidithiobacillus ferrooxidans. Trans. Nonferr. Metal Soc. 2012, 22, 3147-3155. [CrossRef]

13. Sand, W.; Jozsa, P.G.; Kovacs, Z.M.; Sasaran, N.; Schippers, A. Long-term evaluation of acid rock drainage mitigation measures in large lysimeters. J. Geochem. Explor. 2007, 92, 205-211. [CrossRef]

14. Hu, Z.Q.; Zhang, M.L.; Ma, B.G.; Wang, P. Selective Bactericides for at-Source Pollution Control of Acid Coal Waste Piles. Res. Environ. Sci. 2008, 21, 23-26.

15. Zhang, S.H.; Chen, X.; Gong, W.M.; Wang, Q.; Wang, Q.; Zhang, H.L. Efficacy of killing unicellular algae by isothiazo lintone and toxicity tests. Mar. Environ. Sci. 2004, 23, 64-66.

16. Ye, W.Y.; Cheng, T.F.; Guo, X.Y.; Yu, L. Properties of Poly (Ethylene Glycol)-2, 5-Dimercapto-1, 3, 4-Thiadiazole Copolymer. Petrochem. Technol. 2002, 31, 887-889. 
17. Liu, G.M.; Wan, M.X.; Jia, M.M.; Wang, H.F.; Hu, W.Y.; Huang, B. Effectiveness and Influence Factors of Isothiazolinones in Soil Sterilization. Soils 2018, 50, 101-108.

18. Zhang, L.N.; Gong, X.S.; An, J.; Wei, S.H. Occurrence, degradation and potential ecological risks of Triclosan in environment. Chin. J. Appl. Ecol. 2018, 29, 3139-3146.

19. Jones, R.D.; Jampani, H.B.; Newman, J.L.; Lee, A.S. Triclosan: A review of effectiveness and safety in health care settings. Am. J. Infect. Control 2000, 2, 184-196. [CrossRef]

20. Editorial Board of the Determination Methods for Examination of Water and Wastewater. Determination Methods for Examination of Water and Wastewater, 4th ed.; China Environmental Science Press: Beijing, China, 2002.

21. Siebert, H.M.; Marmulla, R.; Stahmann, K.P. Effect of SDS on planctonic Acidithiobacillus thiooxidans and bioleaching of sand samples. Miner. Eng. 2011, 24, 1128-1131. [CrossRef]

(C) 2020 by the authors. Licensee MDPI, Basel, Switzerland. This article is an open access article distributed under the terms and conditions of the Creative Commons Attribution (CC BY) license (http://creativecommons.org/licenses/by/4.0/). 